\title{
Maatilojen tilastoinnista maatalousyritysten tilastointiin
}

\author{
Hannu Maliniemi \\ Tilastokeskus, Pl 6a,00022 Tilastokeskus, hannu.maliniemi@ tilastokeskus.fi
}

\section{Tiivistelmä}

Verohallinto uudisti maatilatalouden verotuksen muistiinpanovelvollisuutta vuonna 2003 ja uutta päätöstä sovellettiin ensimmäisen kerran vuoden 2004 toteutetussa maatalousverotuksessa. Tämän seurauksena myös Tilastokeskuksessa jouduttiin uudistamaan maatilatalouden veroaineistoihin pohjautuvia tilastoja. Tilastoinnin kannalta verouudistus sisälsi paljon hyvää, esimerkiksi verohallinto on vuodesta 2004 saakka vienyt kaikkien maatalousyrittäjien verotiedot verohallinnon tietokantoihin joista Tilastokeskuksella on ollut mahdollista saada kaikkien maatilayrittäjien tiedot käyttöönsä. Lisäksi maatalouden 2-verolomakkeen uusi tietosisältö antaa joiltain osin aikaisempaan verrattuna tarkempaa tietoa tilan tuloista ja menoista kuin vuoteen 2003 saakka käytetty lomake. Aiemmin maatilayrityskohtaiset verotiedot saatiin paperikopioina vain otokseen valituilta tiloilta, joten maataloustilastoinnin kannalta uudistus merkitsi siirtymistä otosaineistosta kokonaisaineistoon, säästöä taloudellisten ja työvoimaresurssien käytössä, sekä osin laajempia tietoja tilastoyksiköiden verotilinpäätöksistä. Uudistuksen seurauksena päätettiin korvata kaksi maatalous-toimialan tilastoa uudella Maa- ja metsätalousyritysten taloustilastolla.

Suurimpana haasteena uuden tilaston laadinnassa oli kahden hallinnonalan, maa- ja metsätalousministeriön sekä verohallinnon tuottamien rekisteriaineistojen yhdistäminen. Yhdistelyä vaikeutti em. hallintoviranomaisten käyttämät erilaiset yksikkötunnisteet. Verohallinto käyttää maatilan omistavan ja siitä tuloja saavan oikeudellisen yksikön tunnisteena y-tunnusta tai henkilötunnusta. Maa- ja metsätalousministeriö puolestaan käyttää maatilat erottavana tunnisteena maatilatunnusta. Molemmilla hallinnonaloilla on omat tehtävänsä ja siinä mielessä erilaiset tunnukset puoltavat paikkaansa. Maatilatunnus kuvaa lähinnä fyysistä yksikköä, joka pitää sisällään tietyt hehtaarit, rakennukset ja kotieläimet käsittävän kokonaisuuden. Verohallinto puolestaan joutuu pitämään rekisteriä verovelvollisista oikeudellisista yksiköistä. Oikeudellisen yksikön ja maatilan muodostavasta tilastoyksiköstä käytetäänkin uudessa tilastossa nimitystä maatilayritys. Maatila käsite vastaa läheisesti yritysterminologian mukaista toimipaikka käsitettä.

Kahden hallinnonalat tietojen yhdistämisessä onnistuttiin hyvin luotettavasti. Yhdistelyn onnistumista testattiin vuoden 2007 alussa suoritetun tilastokyselyn yhteydessä. Kyselylomakkeelle oli esitäytetty sekä maatilatunnus että y-tunnus. Lomake lähetettiin noin 9000 maatilayrittäjälle, mutta vain muutamassa tapauksessa tunnukset olivat kohdentuneet väärin, nekin yleensä silloin kun tilalla oli vastikään toteutettu sukupolvenvaihdos.

Uusi aineisto muodostaa laajan tietovarannon, jonka perusteella Suomen maatilayritysten taloudesta ja rakenteesta voidaan saada paljon uutta tietoa. Tietovarannon pohjalta laadittavassa uudessa Maa- ja metsätalousyritysten taloustilastossa voidaan kuvata vain yleisellä tasolla maa- ja metsätalousyritysten tuloja, menoja, varoja ja velkoja. Tilastouudistuksen seuraava haaste onkin saattaa aineisto yhä laajempaan tutkimuskäyttöön. Tilastokeskuksen tutkimuslaboratorio voisi antaa mahdollisuuden vieraileville tutkijoille hyödyntää myös maatilayritysaineistoja tulevaisuudessa.

\section{Asiasanat: maatila, maatilayritys, maatilatalous, oikeudellinen yksikkö, toimiala, taloustilasto}




\section{Johdanto}

Rekisteriaineistoilla on keskeinen rooli tilastotuotannossa. Ensimmäinen maatalouslaskenta ja maatilarekisterin luonti 1970 luvun alussa, sekä maatilatalouden verolain (MVL) voimaantulo vuonna 1967 mahdollistivat maatilatalouden veroaineistoihin perustuvan tilastotuotannon aloittamisen Tilastokeskuksessa 1970 luvun alkupuolella. Viitevuodesta 1973 vuoteen 2004 saakka Tilastokeskus onkin toimittanut maatilakohtaiseen otanta-aineistoon pohjautuvaa Maatilatalouden yritys ja tulotilastoa, sekä luonnollisten henkilöiden omistamien maatilojen omistajapuolisoiden henkilöveroaineistoon perustuvaa Maatilatalouden tulo- ja verotilastoa.

Tilastojen tietolähteinä käytettävissä rekisteriaineistoissa tapahtuneet muutokset ovat mahdollistaneet ja toisaalta luoneet paineita muuttaa vakiintuneita tilastointikäytäntöjä. Maatilatalouden verolainsäädännön ja verolomakkeiden uudistus aiheutti tilastonlaatijoille päänvaivaa mm. 1990 luvun alkupuolella, jolloin maatilatalouden 2-verolomakkeen tietosisältöä supistettiin oleellisesti vanhasta lomakeformaatista. Tällöin verotietoja alettiin täydentää suoralla maatiloille suunnatulla tilastokyselyllä. Maa- ja metsätalousministeriön hallinnonalalla tapahtuneet muutokset, erityisesti Suomen liittyminen Euroopan unioniin vuonna 1995, ovat yhdessä atk:n yleistymisen kanssa lisänneet maatila- ja yrityskohtaisen tiedon määrää huomattavasti. Tätä tietoa on ollut mahdollista käyttää myös tilastojen tiedonlähteinä.

Vuonna 2004 tapahtunut maatilatalouden verolomakeuudistus sysäsi jälleen liikkeelle tarpeen uudistaa myös maataloustilastoja. Verohallinto muutti maatalouden harjoittajien muistiinpanovelvollisuutta vuonna 2003 ja uutta päätöstä sovellettiin ensimmäisen kerran vuoden 2004 verotuksessa (Verohallinnon päätös 773/2003). Päätökseen sisältyy uusi tulojen ja menojen kirjaamista koskeva muistiinpanokaava, josta ei ole säädetty aiemmin. Vuoden 2004 veroilmoitus uudistettiin vastaamaan muistiinpanoja, joissa tulot ja menot ryhmitellään arvonlisäverokannan mukaan. Vuodesta 2004 lähtien verohallinto on vienyt myös omiin tietokantoihinsa kaikkien maatilatalouden verolain mukaan verotettujen verovelvollisten 2lomakkeelta saatavat tiedot. Tämä avasi Tilastokeskukselle mahdollisuuden saada kaikkien maatalousyrittäjien verotiedot suoraan verohallinnon tietokannoista, kun aiemmin verotiedot oli saatu paperikopioina otokseen valituilta tiloilta. Tässä vaiheessa oli mahdollista yhdistää kahden samalta toimialalta tuotetun tilaston tietosisältö yhdeksi uudeksi Maa- ja metsätalousyritysten taloustilastoksi, joka korvaa viitevuodesta 2005 lähtien kaksi alussa mainittua tilastoa.

Suurimpana haasteena uuden tilaston laadinnassa oli kahden hallinnonalan, maa- ja metsätalousministeriön sekä verohallinnon tuottamien rekisteriaineistojen yhdistäminen. Aiemmin otantaan kuuluvien maatilojen tiedot on yhdistetty yrittäjän verotietoihin paikallisten verotoimistojen henkilökunnan toimesta; lista otokseen kuuluvista maatiloista lähetettiin verotoimistoihin, joissa verovirkailijat hakivat oikean viljelijän verotiedot kullekin maatilalle ja toimittivat ne paperikopioina Tilastokeskukseen. Vuodesta 2004 lähtien tätä paikallistuntemusta ei voitu enää käyttää, vaan maa- ja metsätalousministeriön tilastollisen maatilarekisterin tietojen ja tilan omistavan oikeudellisen yksikön verotietojen yhdistäminen on jouduttu suorittamaan Tilastokeskuksessa. Yhdistelyn tekee hankalaksi em. hallintoviranomaisten käyttämät erilaiset yksikkötunnisteet. Kun verohallinto käyttää maatilan omistavan oikeudellisen yksikön tunnisteena ytunnusta tai henkilötunnusta, niin maa- ja metsätalousministeriö käyttää maatilat erottavana tunnisteena maatilatunnusta. Maatilatunnus kuvaakin lähinnä fyysistä yksikköä, joka pitää sisällään tietyt hehtaarit, rakennukset ja kotieläimet käsittävän kokonaisuuden. Maatilatunnus on pääsääntöisesti muuttumaton esimerkiksi tilan siirtyessä sukupolvelta toiselle. Y-tunnus annetaan kaikille arvonlisäveron alaisille yksiköille erikseen. 


\section{Aineisto ja menetelmät}

Maa- ja metsätalousyritysten taloustilastoa varten on viitevuodesta 2004 lähtien ollut käytettävissä kaikkien maatilatalouden verolain mukaan verotettujen yksiköiden 2-verolomakkeiden verotiedot. Lisäksi tilastoa varten on hankittu kaikkien vuosivalvottavien alkutuotannosta arvonlisäverovelvollisten yksiköiden alvtiedot, sekä kaikkien metsänomistajien metsäverotusta koskevat tiedot. Tilastokeskuksella on lisäksi käytössään kaikkien verovelvollisten henkilöiden vuosi-ilmoitustiedot sekä hyvin laajat yritysverotusta koskevat aineistot. Metsäverotiedot jakaantuivat vuoteen 2005 saakka verohallinnossa kahteen eri tietokantaan; pinta-alaverotuksen piiriin kuuluvien metsänomistajien verotietoja ylläpidettiin verohallinnon omassa maatilarekisterissä ja puun myyntituloverotukseen kuuluvia verotietoja ylläpidettiin omassa järjestelmässään. Viitevuodesta 2006 lähtien kaikkia metsätuloja verotetaan puun myyntitulojen mukaan.

Maa- ja metsätalousministeriön hallinnonalan rekistereistä uutta tilastoa varten on käytettävissä mm. maa- ja metsätalousministeriön tietopalvelukeskuksen ylläpitämä tilastollinen maatilarekisteri, sekä lähinnä maataloustukien hallinnointia varten ylläpidettävät maaseutuelinkeinorekisterin tiedot, jotka sisältävät mm. tilakohtaiset kasvinviljely-, kotieläin- ja tukitiedot.

Rekisteritietoja on täydennetty suoralla maatiloille suunnatulla tilastokyselyllä, jolla pyritään selvittämään muutamien 2-verolomakken tulo- ja menoerien yksityiskohtaisempaa sisältöä. Kyselylomake löytyy tilastokeskuksen sivulta: http://tilastokeskus.fi/keruu/mmtal/lomakkeet.html. Otokseen kuului vuosina 2004 - 2006 noin 9000 maatilaa. Verouudistuksen seurauksena tilastolomaketta jouduttiin uudistamaan huomattavasti entisestä muodostaan. Ehkä tästä syystä vastauskato jäi vuosina 2004-2005 lähes puoleen. Sekä uusi verolomake että tilastolomake koettiin vaikeaselkoiseksi vanhaan verrattuna. Useat kaupalliset maatalouden verokirjanpito-ohjelmat tuottivat myös tilastolomakkeen yhdessä verolomakkeiden kanssa, mutta joidenkin ohjelmien kohdalla tilastolomakkeen tulostus ei ollut toiminnassa vuonna 2004 ja 2005. Tällä hetkellä kaikkiaan seitsemän kirjanpito-ohjelmaa tuottaa myös tilastolomakkeen tiedot, joten vastauskato tullee pienenemään jatkossa.

Tilaston kohdeperusjoukko muodostettiin siten, että tilastollisen maatilarekisterin maatilalle etsittiin aktiivisimman tilalta tuloja saaneen MVL:n mukaan verotetun oikeudellisen yksikön verotiedot. Kohdentamisessa käytettiin apuna maaseutuelinkeinorekisterin asiakastietoja, verohallinnon yritysasiakastietoja, sekä muita veroaineistoja. Tietojen kohdentamisessa ilmeni haasteita ja vaikeuksia; samalla maatilalla saattoi toimia useita oikeudellisia yksiköitä tai yrityksiä, ja toisaalta yhdellä oikeudellisella yksiköllä saattoi olla hallussaan useampia maatiloja. Esimerkiksi sukupolvenvaihdoksen molemmin puolin maatilalla toimii usein kaksi erillistä MVL yksikköä, uusi ja vanha isäntä. Jos vanha isäntä sai esimerkiksi vain jaksotettuja kotieläintuloja, katsottiin hänen olevan ns. passiiviviljelijä. Tämän seurauksena jouduttiin pohtimaan tilastossa käytettyä terminologiaa uudelleen. Aiemmin maatilatalouden verotilastojen kohdeperusjoukko muodostettiin yksistään maatilarekisterin pohjalta, jolloin myös tilastoyksiköstä on käytetty nimitystä maatila. Uudessa tilanteessa kullekin maatilalle yhdistettiin vain yhden oikeudellisen yksikön verotiedot, jolloin kumpikaan em. termeistä ei täydellisesti kuvaa uutta muodostettua tilastoyksikköä. Tämän yhdistelmän perusteella syntyneestä tilastoyksiköstä käytetäänkin uudessa tilastossa nimitystä maatilayritys. Muuhun yritystalouden terminologiaan rinnastamalla maatilan voidaan ajatella kuvaava yrityksen toimipaikkaa. Uusi tilasto selventää myös käsitettä tilojen aktiivisuudesta ja passiivisuudesta; vaikka tilastollisesta maatilarekisteristä käytetään myös nimitystä "aktiivitilojen rekisteri", kuuluu näidenkin tilojen joukkoon sellaisia yksiköitä, jotka verottaja tulkitsee ns. harrastetiloiksi ja siten tiloilta mahdollisesti saatavia tuloja ei veroteta MVL:n mukaan. Toisaalta yli 70000 MVL:n alaista yksikköä toimii myös ns. passiivitiloilla. Nämä yksiköt saavat esimerkiksi MVL:n alaisia maan vuokratuloja. Uuden tilastoaineiston perusteella on siten ensimmäistä kertaa mahdollisuus tehdä päätelmiä esimerkiksi rahavirroista aktiivisilta yksiköiltä passiivisille.

Otosyksiköiden valinnassa käytettävä tapa on ns. kiertävä paneeli, jossa noin puolet otoksesta vaihtuu vuosittain, jolloin sama maatilayritys on tutkimuksessa mukana yleensä kaksi vuotta. Otantaasetelmana on ositettu yksinkertainen satunnaisotanta palauttamatta. Tärkeimpinä osituskriteereinä on tuotantosuunta ja tilakoko. Otos kiintiöidään Neyman-kiintiöinnin mukaan ja kiintiöintimuuttujana on tulos maataloudesta. Otoksesta saadut tulokset painotetaan vastaamaan kokonaisaineistosta saatuja lukuja. Estimoinnin tarkkuuden parantamiseksi tehdään jälkiositus, jonka tärkeimmät kriteerit ovat maatilayrityksen juridinen muoto ja tukialue. Tämän jälkeen jokaiselle ositteelle lasketaan painokerroin ja painot kalibroidaan kaikille otokseen hyväksytyille maatilayrityksille. Kalibroinnissa marginaalimuuttujina 


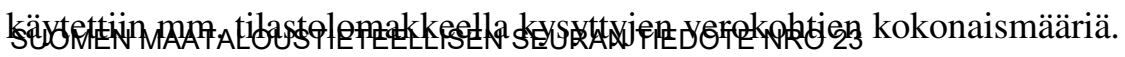

\section{Tulokset ja tulosten tarkastelu}

Tilastouudistuksen päätavoitteeksi asetettiin kahden hallinnonalan aineistojen yhdistäminen, ts. maatilatoimipaikan ja sen oikeudellisen omistajan tiedot pyrittiin kohdentamaan keskenään. Tässä tehtävässä onnistuttiin varsin luotettavasti. Yhdistelyn tuloksena saatua tietoa testattiin vuoden 2006 tilastokyselyt yhteydessä vuoden 2007 alussa, kun noin 9000 maatilayritykseen postitettuun tilastolomakkeeseen esitäytettiin maatilatunnus sekä oikeudellisen omistajan y-tunnus. Alustavassa tarkastuksessa löytyi vain muutama tapaus joissa tunnukset olisivat kohdentuneet väärin, nekin koskivat lähinnä sellaisia tapauksia joissa tilalla oli vasta toteutettu sukupolvenvaihdos.

Tilastokeskuksen toimintastrategiana on "yhdistää tietoaineistot ja asiantuntemus tilastoiksi ja tietopalveluiksi yhteiskunnan tarpeisiin, sekä edistää tilastojen käyttöä ja kehittää kansallista tilastotointa." Maa- ja metsätalousyritysten taloustilastoa varten tuotetusta tietovarannosta vuosittain laadittava julkaisu on saatavilla koko laajuudessaan ainoastaan Tilastokeskuksen internet sivuilla osoitteessa http://tilastokeskus.fi/til/mmtal/index.html. Tilaston katsausosaa on mahdollista selata joko html tai pdf muodossa. Tilaston tietokantataulukoista käyttäjän on mahdollista tehdä haluamiansa poimintoja ja muuntaa taulukot esimerkiksi excel muotoon. Tiedot ovat ilmaisia kaikille käyttäjille.

Kokonaisaineistoon perustuvassa uudessa tilastossa yrityskohtaisia tietoja voidaan julkaista jopa kuntatasolla. Muina alueluokkina käytetään maakuntaa sekä EU-tukialuetta. Tietoja on luokiteltu lisäksi tuotantosuunnan, yrityksen juridisen muodon, omistajan iän ja tilakoon mukaan. Tietokantataulukot mahdollistavat myös aiempaa huomattavasti monipuolisempien tarkastelujen tekemisen, koska vanhaa "sivurajoitetta" ei ole enää olemassa. Periaatteena onkin, että tilaston käyttäjä voi itse hakea tietokantatauluista haluamansa tiedon. Aiemmissa tilastoissa oli mahdollista julkaista pääosin vain yhden ulottuvuuden mukaan luokiteltuja taulukoita, kun nyt julkaistavissa tietokantatauluissa on pääsääntöisesti vähintään kaksi ulottuvuutta, esimerkiksi maakunta ja tuotantosuunta.

MVL:n mukaan verotettujen verovelvollisten määrä vuonna 2005 oli 145472 yksikköä. Näistä 66830 yksikön tiedot oli yhdistettävissä maa- ja metsätalousministeriön tietopalvelukeskuksen ylläpitämän maatilarekisterin maatilaan. Kyseiset tilat muodostavat Maa- ja metsätalousyritysten taloustilaston vuoden 2005 perusjoukon. Perusjoukkoon kuuluvista tiloista luonnollisten henkilöiden omistuksessa oli 60124 yritystä, verotusyhtymien omistuksessa 4083 yritystä, kuolinpesien omistuksessa 2592 yritystä ja loput 31 yritystä olivat muiden juridisten omistajien hallinnassa. Maa- ja metsätalousministeriön maatilarekisterin mukaan Suomessa oli vuonna 2005 kaikkiaan 69517 aktiivista maatilaa, joten kyseiseen rekisteriin kuuluvista maatiloista ainoastaan 2687 jää tämän tilaston perusjoukon ulkopuolelle siitä syystä, että niiltä saatuja tuloja ei veroteta maatilatalouden verolainsäädännön mukaan; ts. kyseiset tilat ovat joko ns. harrastetiloja tai kuuluvat elinkeinoverotuksen piiriin. Oheisessa taulukossa on esitetty kaikkien MVL:n alaisten yksiköiden tuloja ja menoja vuosilta 2004 ja 2005 aktiivisilta ja passiivisilta yksiköiltä erikseen. Passiivisten yksiköiden tilinpäätöksistä ei ole ennen tätä tilastoa voitu esittää mitään tietoja Suomessa, joten tässäkin mielessä uusi tilasto tuottaa uutta tietoa.

Kokonaistasolla MVL:n alaiset tulot kasvoivat noin 35 miljoonaa euroa vuodesta 2004 vuoteen 2005. Koska maatalouden menot kasvoivat samanaikaisesti lähes 70 milj. euroa, aleni maatalouden tulos noin 35 milj. euroa. Perusjoukkoon kuuluvien maatilayritysten maatalouden tulos aleni noin 51 milj. euroa, kun vastaavasti muilla MVL:n alaisilla yksiköillä tulos kasvoi noin 15 milj. euroa. Maataloustukien määrä kasvoi vuodesta 2004 vuoteen 2005 yli 40 milj. euroa. Varsinaisista myyntituloista kasvoivat voimakkaimmin eläinten myyntitulot (alv $22 \%$ ), 39 milj. euroa. Tähän ryhmään kuuluvat sekä teuraaksi että eloon myytävät eläimet. Seuraavaksi eniten kasvoivat muut myyntitulot (alv $22 \%$ ), yhteensä 29 milj. euroa. Tässä kohdassa ilmoitetaan mm. yritysten konetyöstä yms. urakoinnista saamat myyntitulot. Maatalouden ostomenot (alv $22 \%$ ) kasvoivat edellisvuodesta noin 77 miljoonaa euroa. Muissa menoerissä muutokset olivat huomattavasti vähäisempiä. 


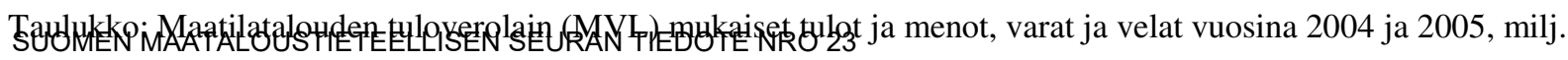
euroa

\begin{tabular}{|c|c|c|c|c|c|c|}
\hline \multirow[b]{2}{*}{ Vuosi } & \multicolumn{2}{|c|}{ Kaikki verovelvolliset } & \multicolumn{2}{|c|}{$\begin{array}{l}\text { Maatilarekisteriin } \\
\text { kuuluvat yritykset }\end{array}$} & \multicolumn{2}{|c|}{$\begin{array}{l}\text { Muut MVL mukaan } \\
\text { verovelvolliset } \\
\text { (ns. passiiviyksiköt) }\end{array}$} \\
\hline & 2004 & 2005 & 2004 & 2005 & 2004 & 2005 \\
\hline Yritysten/yksiköiden lukumäärä & 145062 & 145472 & 68896 & 66830 & 76166 & 78642 \\
\hline Maataloustuotteiden myyntitulot yht. & 2324 & 2298 & 2233 & 2199 & 91 & 99 \\
\hline - Eläinten myyntitulot, alv 22 \% & 592 & 631 & 579 & 611 & 13 & 20 \\
\hline - Jaksotetut Eläinten myyntitulot & 12 & 12 & 8 & 8 & 4 & 4 \\
\hline - Muut myyntitulot, alv $22 \%$ & 295 & 324 & 257 & 284 & 37 & 39 \\
\hline $\begin{array}{l}\text { - Kotieläintuotteiden myyntitulo, alv } \\
17 \%\end{array}$ & 919 & 847 & 904 & 833 & 15 & 14 \\
\hline - Kasvinviljelytuott. myyntitulo, alv $17 \%$ & 506 & 496 & 484 & 471 & 22 & 25 \\
\hline Majoituspalvelut ym., alv $8 \%$ & 21 & 23 & 17 & 18 & 4 & 5 \\
\hline Maataloustuet & 1745 & 1786 & 1709 & 1748 & 35 & 38 \\
\hline Tasausvarausten suora tuloutus & 40 & 48 & 34 & 41 & 5 & 6 \\
\hline Muut tulot, alv $0 \%$ & 181 & 190 & 68 & 66 & 113 & 124 \\
\hline Tulot yhteensä & 4310 & 4345 & 4061 & 4073 & 249 & 272 \\
\hline Palkkamenot & 112 & 114 & 107 & 108 & 5 & 6 \\
\hline Ostomenot, alv $22 \%$ & 1388 & 1465 & 1335 & 1406 & 53 & 59 \\
\hline Jaksotetut eläinten hankintamenot & 6 & 7 & 6 & 6 & 1 & 0 \\
\hline Ostomenot, alv 8 ja $17 \%$ & 464 & 457 & 454 & 447 & 10 & 10 \\
\hline Muut menot, alv $0 \%$ & 466 & 482 & 433 & 448 & 33 & 34 \\
\hline Poistot & 473 & 463 & 450 & 439 & 23 & 23 \\
\hline - Rakennukset & 95 & 94 & 87 & 87 & 7 & 7 \\
\hline - Koneet ja kalusto & 358 & 348 & 344 & 334 & 14 & 14 \\
\hline - Ojat, sillat yms. & 21 & 21 & 19 & 19 & 2 & 2 \\
\hline Tehty tasausvaraus & 159 & 144 & 155 & 140 & 4 & 4 \\
\hline Menot yhteensä & 3068 & 3126 & 2939 & 2988 & 129 & 137 \\
\hline Voitto & 1243 & 1219 & 1122 & 1084 & 120 & 135 \\
\hline Korjauserät & 5 & -6 & 0 & -12 & 5 & 5 \\
\hline Maatalouden velkojen korot & 103 & 105 & 97 & 99 & 6 & 6 \\
\hline Tulos maataloudesta & 1145 & 1109 & 1025 & 974 & 120 & 135 \\
\hline Maatalouden varat & 4366 & 4598 & 3901 & 4089 & 466 & 508 \\
\hline Maatalouden velat & 2797 & 2909 & 2672 & 2789 & 125 & 120 \\
\hline
\end{tabular}

Metsätalouden osalta uuden tilaston kohdeperusjoukkoon kuuluvat verovuodesta 2006 lähtien maatilametsänomistajien lisäksi myös kaikki ns. kaupunkilaismetsänomistajat. Aiemmin toimitettu Maatilatalouden yritys- ja tulotilasto sisälsi vain otostilojen tietoihin perustuvan kuvauksen maatilametsänomistajien metsätaloudesta. Koska kaikkien metsänomistajien puunmyyntituloja on verotettu vuodesta 2006 lähtien puun myyntitulojen perusteella, saadaan uuden tilaston perusteella kattava kuva koko valtakunnan puun myyntituloista ja metsätalouden menoista. Metsätaloudesta julkaistava tietosisältö kattaa lähes kaikki tiedot metsätalouden 2c-verolomakkeelta yhdistettynä verohallinnon kiinteistötietoihin.

Henkilöveroaineistoihin pohjautuvat tiedot julkaistaan omissa tietokantatauluissa vähintään vastaavassa laajuudessa kuin ne julkaistiin aiemmin Maatilatalouden tulo- ja verotilastossa. Henkilöverotietojen osalta kohdeperusjoukko muodostetaan siten, että esimerkiksi vuoden 2005 tilaston koko kohdeperusjoukon 66830 maatilayrityksistä valitaan luonnollisten henkilöiden omistamat yksiköt ja haetaan heidän, sekä heidän puolisoiden verotiedot jotka summataan yhteen. Henkilöverotiedot julkaistaan vain niiden tilastoyksiköiden osalta joilla verotuskunta on sama kuin maatilan sijaintikunta. 


\section{Johtopäätökset}

Yrityskohtaiset veroaineistot on yhdistetty maaseutuelinkeinorekisterin tietoihin ensimmäistä kertaa yksikkötasolla tilastointia ja tutkimusta varten. Uusi aineisto muodostaa laajan tietovarannon tilastointia ja taloudellista tutkimusta varten. Tietovarannon pohjalta laadittavassa uudessa Maa- ja metsätalousyritysten taloustilastossa voidaan kuvata vain yleisellä tasolla maa- ja metsätalousyritysten tuloja, menoja, varoja ja velkoja. Toisaalta internet palvelussa esitettävät tietokantataulut mahdollistavat tilastotiedon julkaisemisen huomattavasti laajemmin kuin aiemmat painetut julkaisut, jolloin tilaston käyttäjät voivat itse hakea tietokantatauluista kaipaamiaan tietoja. Tietokantataulujen heikkoutena on se, että yksittäisen tilastotiedon käyttäjä joutuu omaksumaan uuden työvälineen tilastotiedon hakemiseen ja lukemiseen.

Kokonaisaineisto mahdollistaa jatkossa pitkien aikasarjojen ja paneeliaineistojen muodostamisen. Tämä avaa huomattavan määrän mahdollisuuksia tehdä erilaisia yritysanalyysejä uudesta yhdistelmäaineistosta. Esimerkiksi ajankohtaisen 141-tuen leikkauksen vaikutuksia maatilayritysten talouteen voidaan arvioida kaikilta tuen piiriin kuuluvilta tiloilta erikseen. Yrityksiä voidaan ryhmitellä hyvin tarkasti koon, tuotantosuunnan, kasvinviljely- ja kotieläintietojen perusteella ja verrata niiden saamaa 141-tukea, muita tuloja, menoja, varoja, velkoja sekä maatalouden tuloksen kehittymistä pitkällä ajanjaksolla. Yrityksistä voidaan muodostaa paneeliaineistoja, kuten uudessa tilastossa on tehty jo henkilöverotietojen osalta.

Suurimpana haasteena jatkossa on tilastoa varten tuotetun tietovarannon parempi hyödyntäminen niin tilastoja kuin tutkimusta varten. Tilastokeskuksen perustehtävänä on tuottaa laadukkaita tietovarantoja, sekä laatia niiden pohjalta yhteiskunnan tarpeisiin erilaisia tilastoja. Tietovarantojen pohjalta suoritettava tutkimus tulee vasta näiden perustehtävien jälkeen. Tilastokeskuksen tietosuojaperiaatteiden mukaan koko perusjoukkoa koskevia tilastoaineistoja ei voida luovuttaa Tilastokeskuksen ulkopuolelle missään muodossa. Tämän ongelman ratkaisuksi Tilastokeskus on perustanut oman tutkimuslaboratorion, jossa on mahdollista tutkia yritys- ja toimipaikka-aineistoja taloustieteellisiin tutkimustarkoituksiin. Valmiiden aineistojen lisäksi aineistoja voidaan yhdistellä kyseessä olevan tutkimusongelman mukaisesti. Tutkimuslaboratoriossa voivat vierailevat tutkijat käyttää yritys- ja toimipaikka-aineistoja varatuilla tutkijapaikoilla

Toinen haaste jatkossa on yhä lisääntyvä yhtiömuotoinen yrittäminen maatiloilla. Yhtiömuotoiset maatilayritykset kuuluvat usein miten elinkeinoverolain piiriin, joten ne eivät toistaiseksi kuulu tämän Maaja metsätalousyritysten taloustilaston perusjoukkoon. Jatkossa on tarve selvittää myös näihin juridisiin omistusmuotoihin kuuluvien maatilayritysten tilinpäätöstietoja esimerkiksi omana osajoukkona Maa- ja metsätalousyritysten taloustilastossa. 